\title{
Sub Clinical Infection by Helminthic and Coccidian Parasites in a Confined Dairy Calf
}

\author{
S. Saravanan* and K.M. Palanivel
}

Department of Veterinary Preventive Medicine, Veterinary College and Research Institute, Namakkal-637 002, Tamil Nadu Veterinary Animal Sciences University, Tamil Nadu, India

*Corresponding author

\section{A B S T R A C T}

\section{Keywords}

Dairy calf,

Subclinical

parasitism, $M$.

expansa, E. bovis

\section{Article Info}

Accepted:

10 January 2018

Available Online:

10 February 2018
A female jersey dairy calf of three months old under intensive management presented with normal appetence but emaciation and stunted growth was diagnosed with subclinical parasitism by the tapeworm, Moniezia expansa and intestinal coccidia, Eimeria bovis diagnosed by faecal examination. Laboratory investigation revealed remarkable alterations in biochemical values however no changes in haematological values. Successful recovery was observed by treatment with broad spectrum anthelmintics and an anticoccidial at recommended dosage along with supportive therapy.

\section{Introduction}

Gastro-intestinal helminth infection in dairy cattle causes significant economic losses throughout the world especially in developing countries where the animal owners belong to marginal income group (Lalrinkima et al., 2016). Cattle represents a valuable asset in both traditional and modern agriculture as they provide milk, meat, skin and draught power (Nnabuife et al., 2013).

Neverthless, due to improper management, unhygienic conditions and improper use of anthelmintics, dairy cattle have been suffering from helminthic infections (Swarnakar et al.,
2015), amongst which the cestode, Moniezia expansa is common inhabiting the small intestine of ruminants, however associated with no specific or serious clinical signs. This parasite is especially prevalent among grazing animals, however rarely found among confined animals (Leland et al., 1973) and the hence report on infection in dairy calves under intensive management is limited. However, a heavy worm burden results in persistent diarrhoea and this could lead to reduced growth rate and reduced nutrient utilization in infested calves and further calves have low market value at auction as they expel proglottid segments in their faeces (Takao Irie et al., 2013 and Swarnakar et al., 2015). 
Coccidiosis is also one of the most pathogenic intestinal diseases caused by different species of Eimeria (Almeida et al., 2011) and particularly a problem of animals kept under intensive husbandry practices.

In associations with other enteropathogens, coccidia have been indicated as an important cause of diarrhea in calves (Das and Laha, 2017). Coccidiosis, caused by intestinal protozoa E. bovis and E. zuernii, results in serious health problems leading to reduction in feed consumption, body weight, and feed conversion with a mortality up to $24 \%$ in some cases.

In cross bred calves, it causes severe diarrhea, dysentery, dehydration, unthriftyness, anorexia, weakness and recumbency. However, the information on the haematological and biochemical alterations in tapeworm infestations is also scanty. Hence, this paper presents concurrent and subclinical parasitism by $M$. expansa and E. bovis in dairy calf under intensive management with a note on haematological and biochemical analysis.

\section{Materials and Methods}

A three months old female Jersey calf was presented at Teaching Veterinary Clinical Complex, Veterinary College and Research Institute, Namakkal during May month with the signs of hard pellety faeces with tapeworm segments, normal appetence, weakness, stunted growth and emaciation, and the calf was never dewormed.

On clinical examination, heart rate- $87 /$ minute, respiration rate-29/minute, rectal temperature $38.1^{\circ} \mathrm{C}$ and congested conjunctival mucous membrane were observed. Fresh faecal sample of about 30 grams per rectum was collected from the calf using sterile plastic gloves and the sample was transported in a clean plastic container to the laboratory and stored at $4{ }^{\circ} \mathrm{C}$ for examination on the same day of collection. Centrifugal sedimentation technique was performed and the sediment was examined microscopically for the presence of eggs which were identified based on morphological characters and (Soulsby, 1982). Oocysts were identified, allowed to sporulate and flotation technique was performed using saturated sodium chloride solution for separation of oocysts (Anonymous, 1986).

\section{Results and Discussion}

Microscopic examination of the sample revealed typical stray sporulated oocysts of Eimeria bovis with four sporocysts, each containing two sporozoites. The faecal sample voided had numerous mature segments which when examined microscopically revealed $M$. expansa based on the short distribution of interproglottid glands and eggs of Moniezia spp. (+++) could be demonstrated in the faecal sample. In this study, coccidiosis was observed in three months old young calf which is in accordance with Singh et al., (2008) who also reported an infection of Eimeria sp. in neonatal buffalo calves of less than 3 months. This case though parasitized by intestinal helminths, did not manifest any clinical signs of coccidiosis as reported by previous authors (Das and Laha, 2017). However, concurrent parasitism with E. bovis could be associated with low immunity and increased susceptibility to other diseases due to the malnutrition associated with the poor absorption of digested food (Kuchai et al., 2013).

The serum haematological analysis of the case revealed no alterations in the differential count (neutrophils- $33.0 \%$, lymphocytes-60.0\%, eosinophils-1.0\%, monocytes-6.0\% and no basophils) and haematological values (haemoglobin-15.3 gm/dl, packed cell volume-46.0\%, red blood cells-7.6 x $10^{6} / \mathrm{ml}$ and white blood cells- $6.8 \times 10^{3} / \mathrm{ml}$ ) (Fig. 1-3). 
Fig.1 An emaciated three months old female Jersey calf voiding faeces with tapeworm segments
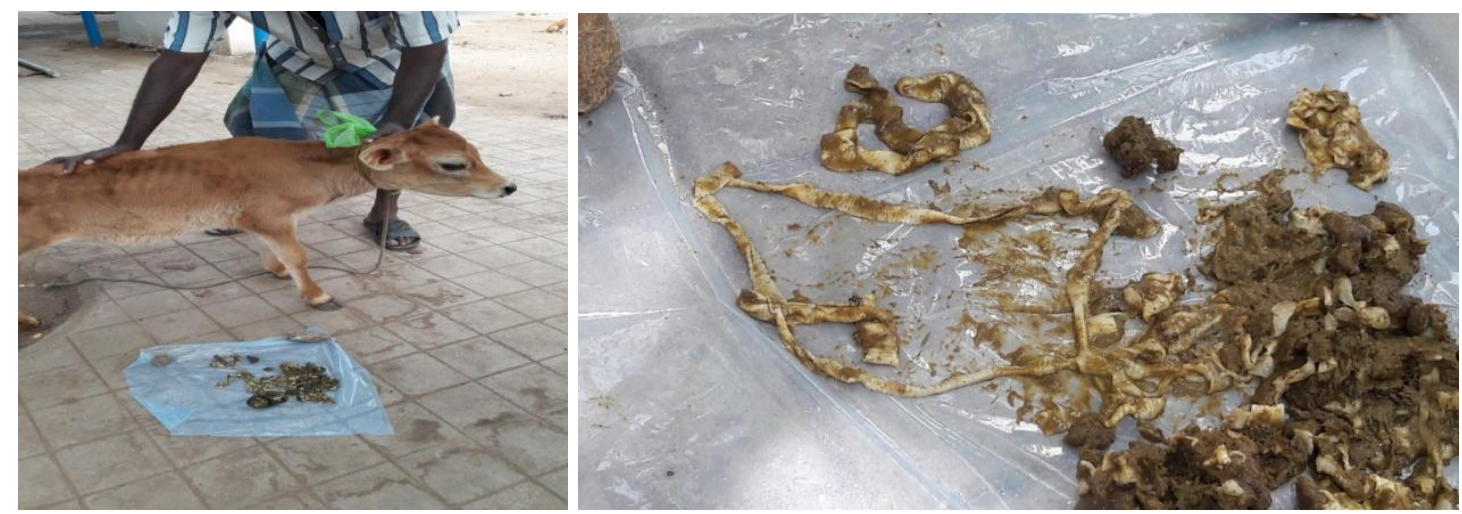

Fig.2 Irregularly triangular eggs of Moniezia expansa in the faeces of jersey calf by microscopic examination (10x and 40x)

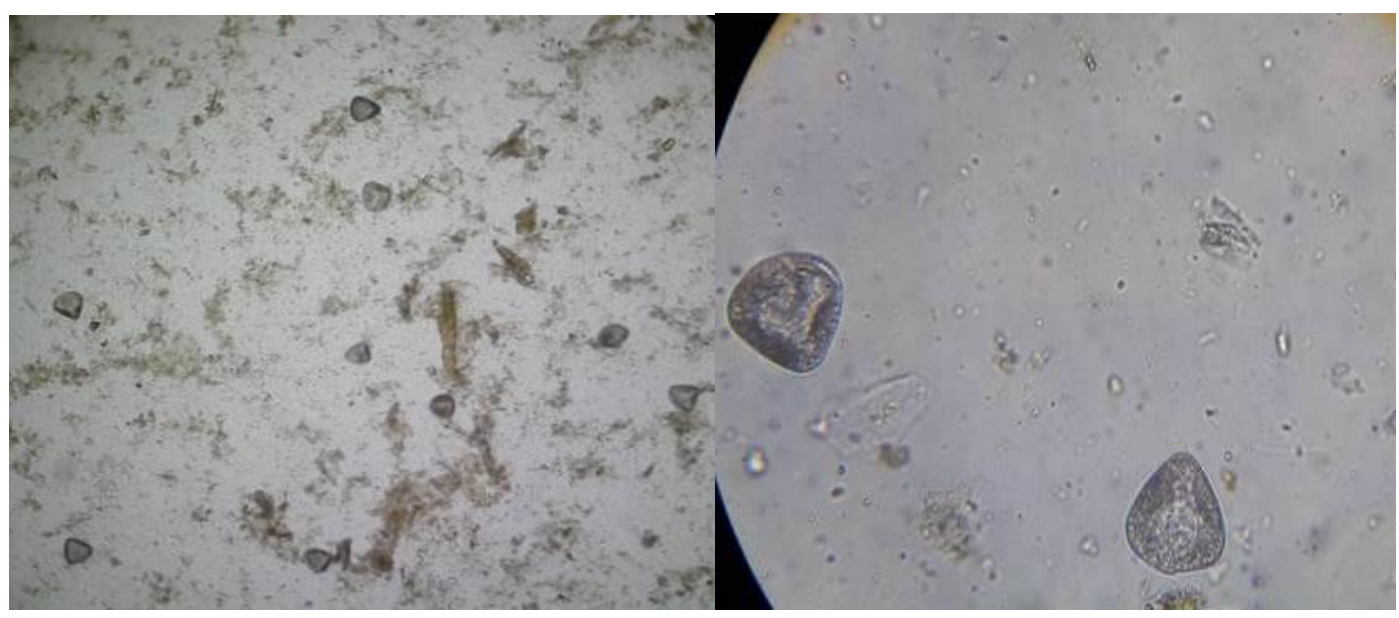

Fig.3 Unsporulated oocysts of pathogenic Eimeria bovis from the faeces of the subclinical case (10x)

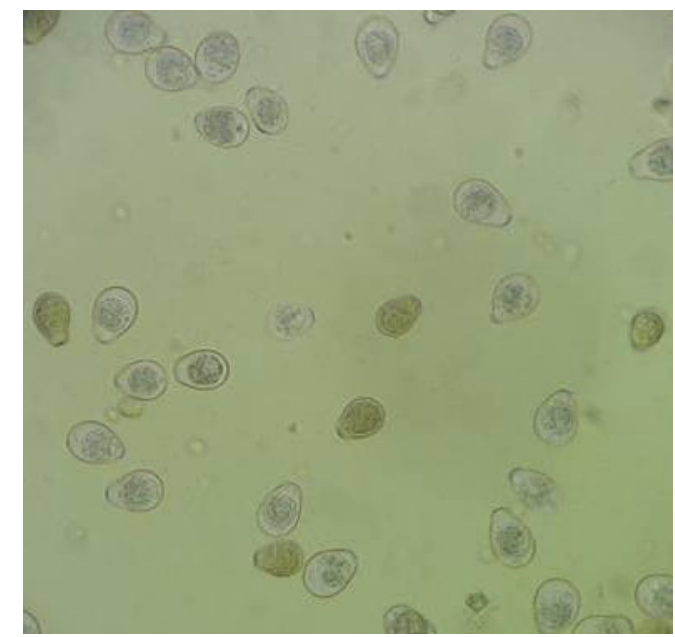


However, serum biochemical analysis revealed mild hypoproteinaemia $(6.11 \mathrm{~g} / \mathrm{dl})$, hypoalbuminaemia $(2.7 \mathrm{~g} / \mathrm{dl})$, hypocalcaemia (6.93 $\mathrm{mg} / \mathrm{dl})$, elevated aspartate aminotransferase $245.8 \mathrm{u} / \mathrm{l}$ and alanine aminotransferase $(91.3 \mathrm{u} / \mathrm{l})$ however with normal globulin (3.34 g/dl), phosphorus (7.29 $\mathrm{mg} / \mathrm{dl})$ and glucose $(70.0 \mathrm{mg} / \mathrm{dl})$ levels.

Batykov et al., (1988) also observed a reduction in the serum albumin and elevation in gamma globulin levels in sheep experimentally injected with endotoxins of Moniezia spp. Galdhar and Roy (2004) also stated that helminthiosis could result in excess production of liver enzymes SGOT and SGPT with or without damage to the liver. The results in this study could be attributed to poor absorption of the dietary nutrients from intestinal tract, which might be associated with digestive disturbances caused by parasitic infection (Parsani et al., 2011).

The case responded positively to the treatment with a suspension of fenbendazole and praziquantel (Fentas plus®) @ 1 ml per 3 $\mathrm{kg}$ bwt and amprolium (Coximer® @ $10 \mathrm{mg} / \mathrm{kg}$ bwt for 5 days, as amprolium the thiamine antagonist is generally recommended for the effective treatment of bovine coccidiosis (Karen Bailey, 1994 and Radostits et al., 2006). Supportive therapy included B-complex (Tribivet $\AA$ ) to avoid hypothiaminosis, $25 \%$ dextrose normal saline.

In view of the above, clean calf barn and administration of a broad spectrum anthelmintics in the first month of calves could be an useful approach in the halting the spread of cestodiasis and in the prevention of coccidiosis, adequate nutrition, good hygiene practices, reasonable stock density and prevention of other infections should be considered in association with prophylactic administration of coccidiostats during anticipated periods of risk.

\section{Acknowledgement}

The authors are thankful to the Tamil Nadu Veterinary and Animal Sciences University for providing necessary facilities to carry out this study.

\section{References}

Almeida, V.D.A, V.C.S. Magalhaes, E.S. Muniz-Neta and Munhoz, A.D. 2011. Frequency of species of the genus Eimeria in naturally infected cattle in Southern Bahia, Northeast Brazil. Braz $J$ Vet Parasitol., 20: 78-81.

Anonymous, 1986. Manual Veterinary Parasitological Laboratory Techniques. Ministry of Agriculture, Fisheries and Food. London.

Batykov, T.V., S.P. Zakharov and SilVestrova, I.G. 1988. Efficacy of closantel against Fasciola hepatica and Haemonchus contortus: Field trial in cattle and sheep. Practishe Tierarzi, 77(10):917-922.

Das M and Laha, R. 2017. Parasitic infections of cattle in North Eastern region of India-An overview. Arch Parasitol., 1: 107.

Galdhar, C.N. and Roy, S. 2004. Clinico haematological and biochemical change in cattle during paramphistomosis. Indian Vet. Med.Jour., 28:245-248.

Karen Bailey, 1994. Coccidiosis in farmed ruminants, Surveillance. 21(2):27-28.

Kuchai, J.A. Fayaz Ahmad, M.Z. Chishti and Hidayatullah Tak, 2013. Impact of host's diet and parasite intensity on Morphology of Moniezia expansa. Agric. Biol. J. N. Am., 4(2): 122-125.

Lalrinkima, H., H. Siamthara Freddy, S.K. Borthakur, Ramhermawia Joseph, Patra Gautam, C. Lalawmpuia and Khiangte Lalthansanga. 2016. Prevalence of gastrointestinal parasite infections of cattle in Northeast India bordering to 
Myanmar and Bangladesh. Int. J. Parasit. Res., 8(4):191-193.

Leland, S. E., H.K. Caley and Ridley, R. K. 1973. Incidence of gastrointestinal nematodes in Kansas cattle. Am. J. Vet. Res. 34: 581-585.

Nnabuife, H.E, A.D. Dakul, G.I. Dogo, O.K. Egwu, P.R. Weka, I.N. Ogo, E.O. Onovoh and Obaloto, B.O. 2013. A study on helminthiasis of cattle herds in Kachia grazing reserve (KGR) of Kaduna state, Nigeria. Vet. World, 6(11): 936-940.

Parsani H. R., R.R. Momin, A. Lateef and Hemen Das. 2011. Haematobiochemical alterations in helminths infected donkeys. Wayamba J. Anim. Sci., 112-114.

Radostits, O.M., C.C. Gay, K.W. Hinchcliff and Constable, P.D. 2006. In: Veterinary Medicine- A text book of the diseases of cattle, sheep, goats, pigs and horses. $10^{\text {th }}$ Ed. Elsevier, Edinburgh.

Singh, K., S.K. Mishra, and Pruthi, A.K. 2008. Pathology of parasitic infestations in gastrointestinal tract in buffalo calves. J. Vet. Parasitol., 22: 17-20.

Soulsby, E.J.L.1982. Helminths, arthropods and protozoa of domesticated animals, 7th edition Balliere Tindall, London.

Swarnakar, G. B., B. Bhardawaj, B. Sanger, and Roat, K. 2015. Prevalence of gastrointestinal parasites in cow and buffalo of Udaipur district, India. Int. $J$. Curr. Microbiol. App. Sci., 4 (6): 897902.

Takao Irie, Kohei Sakaguchi, Aino OtaTomita, Miwako Tanida, Kanako Hidaka, Yumi Kirino, Nariaki Nonaka and Yoichiro Horii. 2013. Continuous Moniezia benedeni infection in confined cattle possibly maintained by an intermediate host on the farm. J. Vet. Med. Sci., 75(12): 1585-1589.

\section{How to cite this article:}

Saravanan, S. and Palanivel, K.M. 2018. Sub Clinical Infection by Helminthic and Coccidian Parasites in a Confined Dairy Calf. Int.J.Curr.Microbiol.App.Sci. 7(02): 1171-1175.

doi: https://doi.org/10.20546/ijcmas.2018.702.144 